\title{
Aprendiendo a mirar. La copia como metodología de enseñanza en las asignaturas de dibujo durante el confinamiento
}

\author{
Marta Alonso Rodríguez \\ Noelia Galván Desvaux \\ Raquel Álvarez Arce
}

Abstract

\begin{abstract}
La copia siempre ha despertado recelo y lleva consigo ciertas connotaciones negativas. Los artistas del siglo XV, por ejemplo, ocultaban el uso de cámaras oscuras para sus dibujos, puesto que se pensaba que ese 'calco' de la realidad empleando un artilugio externo a la propia destreza del artista les quitaba mérito a sus representaciones. Encontramos cierta similitud entre esta idea que acepta con cierto recelo el empleo de otros medios para la representación, y el empleo de las nuevas tecnologías para dibujar.

En esta nueva etapa de la enseñanza que nos ha hecho enfrentarnos a nuevas problemáticas como son la distancia y la falta de medios materiales en muchos casos, el retorno a la idea de copia como recurso en la enseñanza nos ha facilitado en cierta medida el dotar a los alumnos de un modelo ya existente para representar. Este hecho sin embargo no ha eliminado la parte imaginativa y de libertad creativa, sino que ha permitido establecer una base sólida a partir de la cual cada alumno ha podido desarrollar su inventiva y explorar diversos medios de representación. Desaparece el miedo al papel en blanco, puesto que se parte de un modelo ya consolidado de base y se agiliza el proceso creativo, permitiendo al alumno romper la barrera de la distancia profesor-alumno en esa etapa inicial de la representación.
\end{abstract}

Palabras clave

dibujo, enseñanza, copia, confinamiento, distancia.

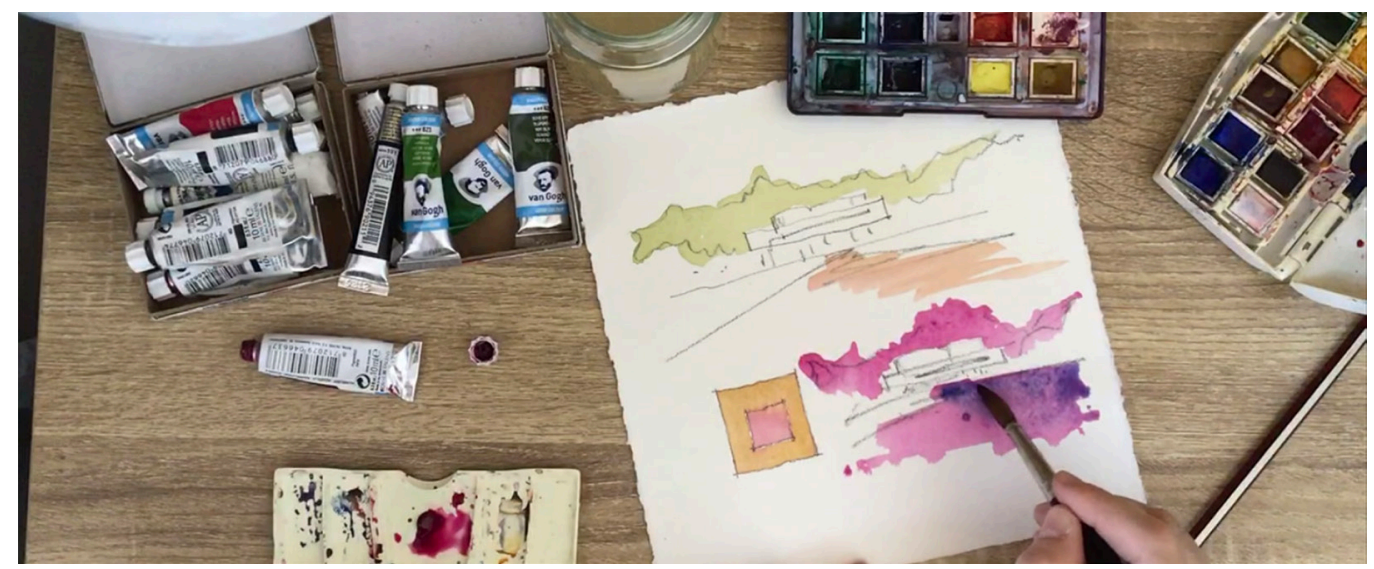




\section{Introducción}

Aunque desconocemos el origen exacto de la copia en sí, si podemos apuntar que el renacimiento supuso un momento de florecimiento para la misma en el mundo del arte, tanto como proceso de aprendizaje como medio de reproducción de un modelo original con el fin de ser difundido [Herrero-Cortell 20 I7]. Copiar a los maestros del arte, como método de aprendizaje, ha sido uno de los primeros sistemas de enseñanza empleados.

Es una práctica cuya eficacia está más que constatada, puesto que a través de la imitación y la copia se consigue asimilar conceptos y conocimientos. Al igual que se ha venido empleando en el mundo de la pintura, copiar a los grandes clásicos con el fin de aprender a pintar, consideramos que este sistema es perfectamente extrapolable al mundo de la representación arquitectónica. En nuestro campo no sólo se puede tener en cuenta a la hora de copiar, el aprender del método proyectual profundizando en cómo el arquitecto relaciona espacios, o sistemas constructivos, sino que el propio estilo de representación empleado por el arquitecto sirve de inspiración para el alumno.

La copia en función de su uso, ha tenido diversos matices. Desde las representaciones realizadas en las tumbas del antiguo Egipto, que copiaban y reproducían una y otra vez los mismos dioses con fines místicos, a las reproducciones religiosas realizadas en la Edad Media con fines doctrinales o evangélicos, pasando por el más trivial que podría considerarse el fin propagandístico, la copia ha ido adquiriendo diversas connotaciones a lo largo de los siglos [Barroso 2017, pp. 22, 23].

Como apuntamos antes, el renacimiento supuso un punto de inflexión para la copia, con la aparición de la especulación sobre la obra artística que conllevó a la creación de talleres de artistas donde aprendices trabajaban con un maestro siguiendo un estilo que en muchos casos hacía imposible distinguir al autor real de una obra (fig. I). Con ello se conseguía aumentar su producción artística, que veía en algunos casos incluso modificado su precio en función de cuanto hubiera de su propia mano en el cuadro. En el siglo XIX la copia como disciplina de aprendizaje volvió a tomar gran importancia, de hecho, como afirma Barroso

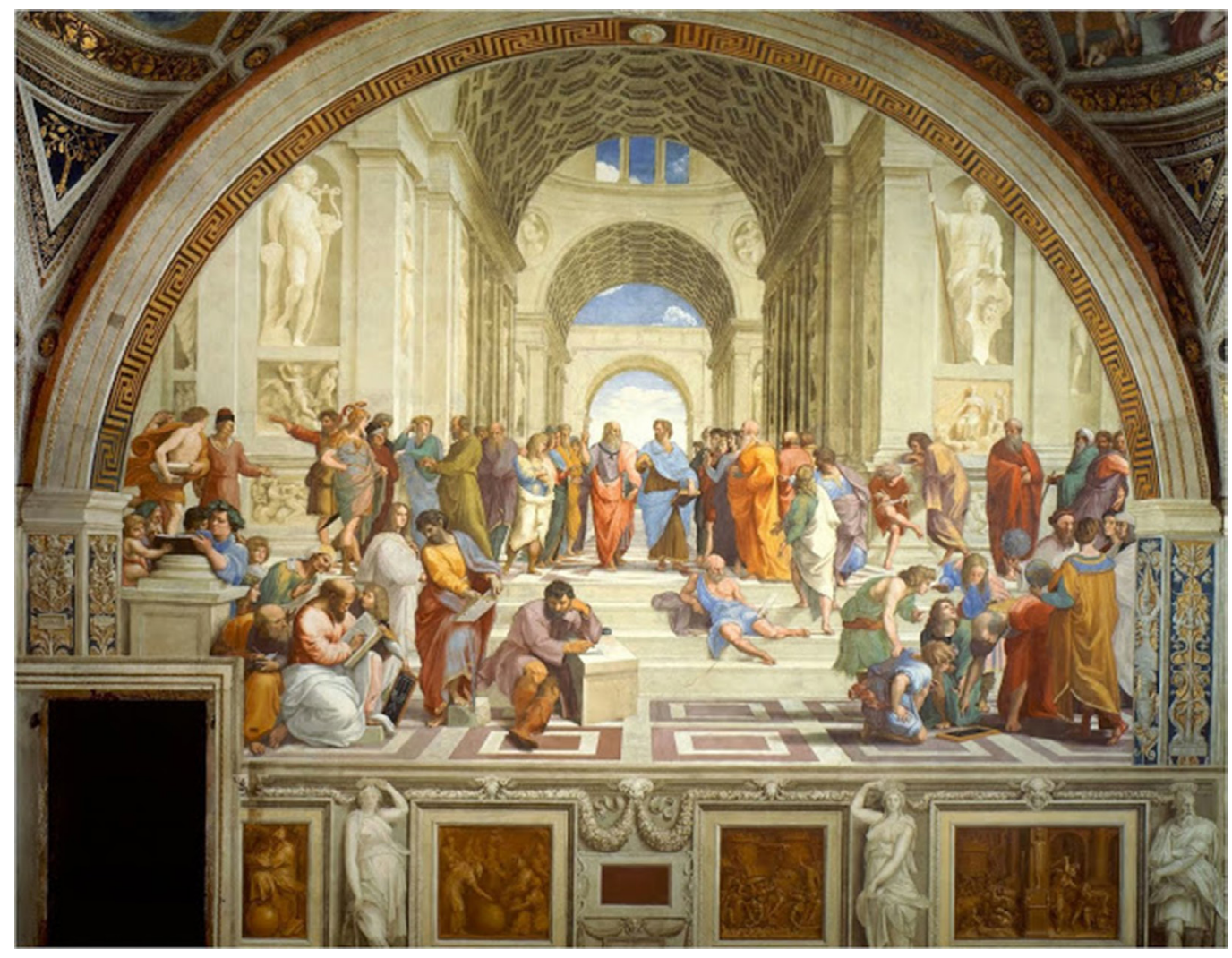


Fig. 2. Álvaro Siza, Dibujo de viaje.

Fig. 3. Maqueta de La casa de piedra en Cáceres (E. Tuñón, alumna del curso de Análisis de formas II).
[2017, p. 26], esta práctica llevada a cabo por numerosos artistas supuso el convertir los grandes museos europeos en lugares de encuentro al que acudían los pintores, coincidiendo por ejemplo Édouard Manet con Edgar Degas enfrente del retrato de la Infanta Margarita, cuadro que ambos estaban copiando y entablando así entre ellos una amistad que duró años. No solamente los aprendices empelaban la copia como método de aprendizaje, sino que los artistas ya consagrados también empleaban esta técnica. Por ejemplo, Rubens gran admirador de la obra de Tiziano, realizó dos viajes a España en los que se dedicó a copiar los cuadros de Tiziano que tenía el rey de España en su colección. Algunas de ellas eran copias literales y en otras introducía pequeñas modificaciones, siendo su obra un homenaje a la original, y suponiendo la obra de Tiziano una fuente de inspiración para realizar una indagación en su estilo pictórico creando sus propias versiones de la inicial [Cantera 2020]. Instruirse a través de la copia de una obra artística no solo posibilita entrenar la mano, sino que permite profundizar y aprender del estilo de otro artista, lo que favorece la creación de un estilo propio moldeando lo aprendido, la adquisición de un lenguaje personal.

Era una práctica común por ejemplo en la ilustración completar la educación de los arquitectos y en general de los artistas con un viaje por Europa para empaparse de las obras clásicas, en especial viajando a Italia. Este sistema de aprendizaje no es otro que el de la copia, al natural eso sí, de un elemento existente con el fin de aprehender del elemento a representar. Esta idea del Grand Tour se remonta de hecho al Renacimiento, cuando los artistas que se lo podían permitir viajaban para adquirir nuevos conocimientos y expandir su mente (fig. 2). Entre los arquitectos que decidieron aprender de las grandes obras clásicas a través de su copia encontramos a Le Corbusier, Gropius o Asplund. En esta época en la que nos encontramos, en la cual viajar se ha convertido en un imposible, la explosión de dibujos e información que podemos encontrar en internet no han permitido acercar estos elementos y poder representarlos a partir de imágenes.

La idea de volver al inicio del aprendizaje de arquitectura, en que se empleaba la copia como punto de partida nos lleva a una reflexión gráfica y un aprendizaje que además se ve impulsada por la facilidad de transferencia de información que nos permiten las plataformas digitales para compartir recursos y las herramientas informáticas con que se cuenta, que permiten romper el aislamiento sufrido por el alumno.
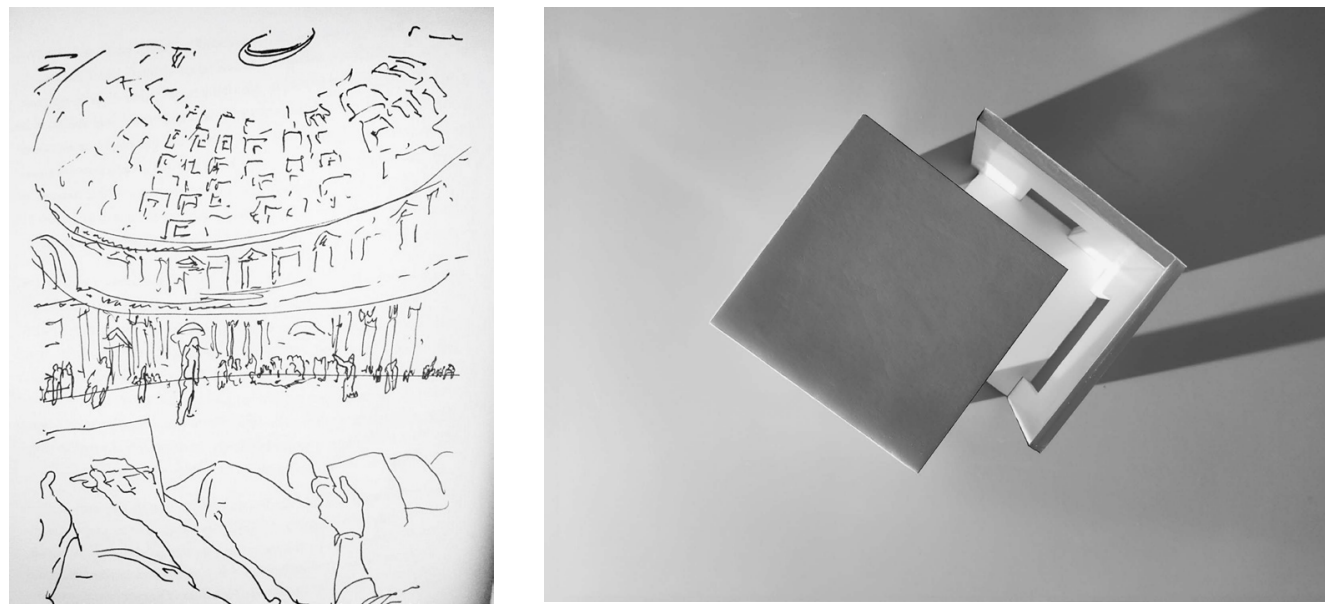

\section{La falta de recursos como impulsora del ingenio}

Nos hemos encontrado con una dualidad, en la cual contábamos con plataformas web y programas de última generación para el desarrollo de las asignaturas, y a la vez la falta de recursos evidente por parte de los alumnos que en muchos casos ni siquiera podían disponer de papel para dibujar. Este hecho derivó sin embargo en una explosión de ingenio por parte de los alumnos, que descubrieron el potencial que cualquier objeto cotidiano tenía como elemento de representación. 
Así en un mero cartón de embalaje encontraban el medio perfecto para la construcción de una maqueta o a partir de una composición de papeles viejos estructuraban una lámina. Sin duda se puede apreciar el paralelismo existente entre esta técnica surgida de la necesidad y el collage, con numerosos seguidores, entre los cuales destacamos las creaciones de la Bauhaus donde el collage fue una de las técnicas más utilizadas por los alumnos (fig. 4). La reutilización de materiales da a los alumnos la oportunidad de reinventarse, y unido a las nuevas tecnologías dan como resultado composiciones donde la expresividad se convierte en el verdadero protagonista (fig. 5).

Fig. 4. Lámina de Análisis de Formas II realizada con la técnica del collage.

Fig. 5. Maqueta de la casa Finney de P. Rudolph, realizada por un alumno de Análisis de formas II con materiales reciclados.
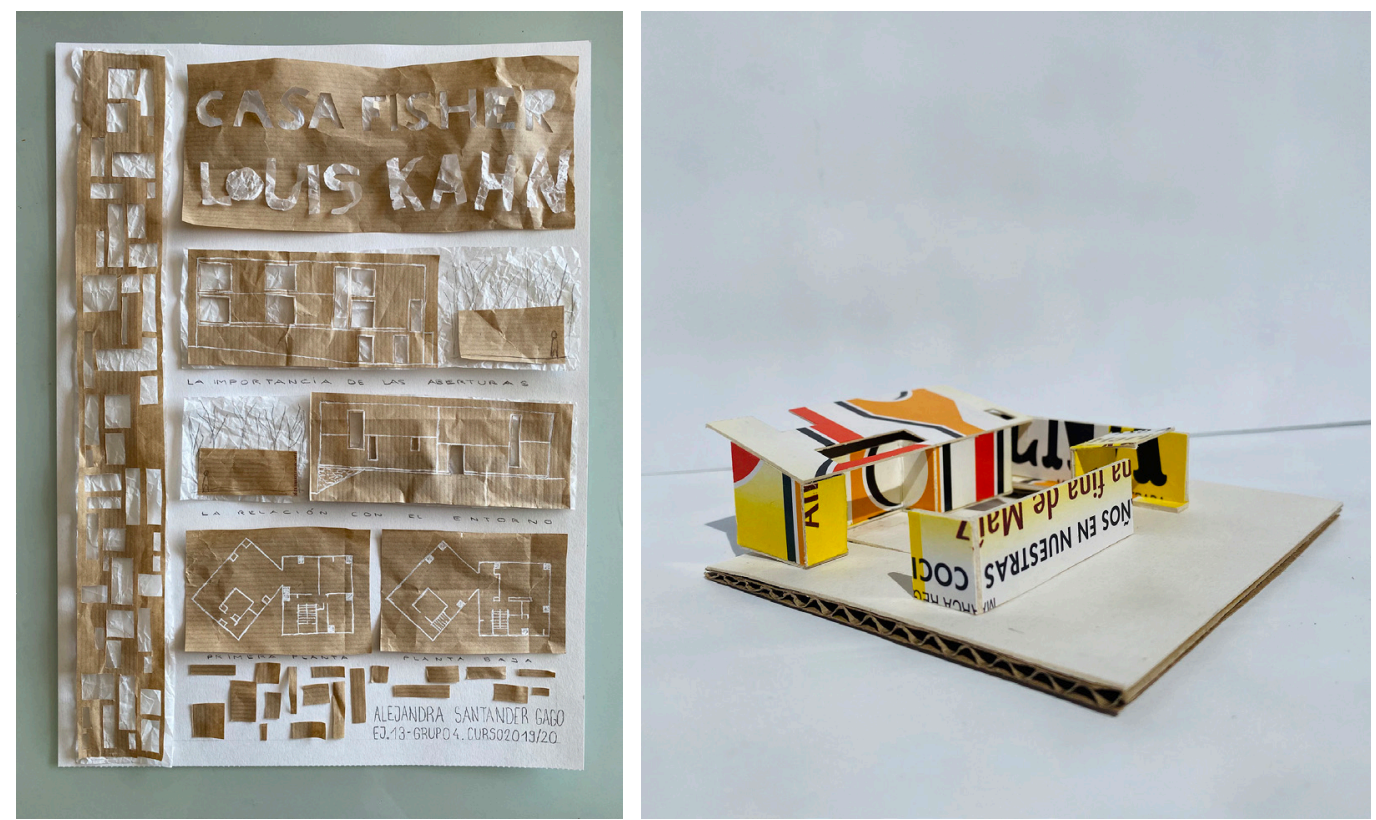

\section{Nuevas tecnologías aplicadas a la docencia online}

Numerosos artistas como Vermeer o Canaletto mantenían en secreto sus técnicas, quizás pensando que el empleo de medios externos a la mano hacía parecer que cualquiera sabía dibujar. Así las cámaras oscuras, y los conocimientos de la óptica y otros artilugios permanecieron ocultos durante siglos. Estos inventos sin duda no otorgaban habilidades al artista, sino que le facilitaban la labor del dibujo, de una manera a nuestro parecer, a las nuevas 'cámaras oscuras' de las que disponemos hoy en día, las tablets y ordenadores. El empleo de estos elementos al igual que entonces, nos trae una ventaja más que evidente, y en la que al menos todos estaremos de acuerdo, que es la agilizad en el proceso de dibujo (fig. 6).

El dibujo a mano se ve complementado con el dominio de los medios virtuales, que otorga a los alumnos de una libertad que les permite explorar en nuevas técnicas y materiales (fig. 7). Así las clases online de la asignatura de Análisis de formas II se han ido desarrollando mediante la combinación de dibujos a mano y maquetas físicas que se podían ver a través de la webcam, y dibujos en tableta digital u ordenador. Cada uno de los métodos gráficos empleados, ha favorecido que el alumno encuentre el medio de expresión con el que mejor desarrollar sus ideas, facilitando que cada uno descubra aquel en que le resulte más apropiado para el fin para el que quiera emplearlo, bien sea plasmar una idea o explicar un concepto.

Aunque el dibujo mediante ordenador pudiera parecer a priori más restrictivo que el dibujo a mano, empleando el software adecuado nos permite exprimir todo el potencial que nos ofrece y los resultados obtenidos nos demuestran que la expresividad del dibujo a mano no 
se ve mermada por el empleo del ordenador. Las tabletas gráficas permiten una transición muy natural del dibujo a mano alzada con lápiz, y además nos otorgan la ventaja de facilitar los cambios sobre el dibujo de manera muy rápida, permitiendo agilizar las correcciones y el empleo de superposiciones de capas en un mismo dibujo.

Consideramos sin embargo después de nuestra experiencia docente que, al margen de la técnica empleada, el hecho de utilizar el dibujo como instrumento del pensamiento, va más allá del propio medio utilizado a tal fin.

Contando con ejemplos previamente escogidos por el profesor, el alumno se apoya en los medios virtuales de manera gradual como complemento a las técnicas tradicionales de enseñanza (fig. 8). Estas clases virtuales apoyadas por las nuevas tecnologías permiten crear un feedback profesor-alumno que plantea estrategias de aprendizaje que les permite desarrollar la capacidad de pensar e intervenir en los diversos procesos de creación e ideación de un proyecto.

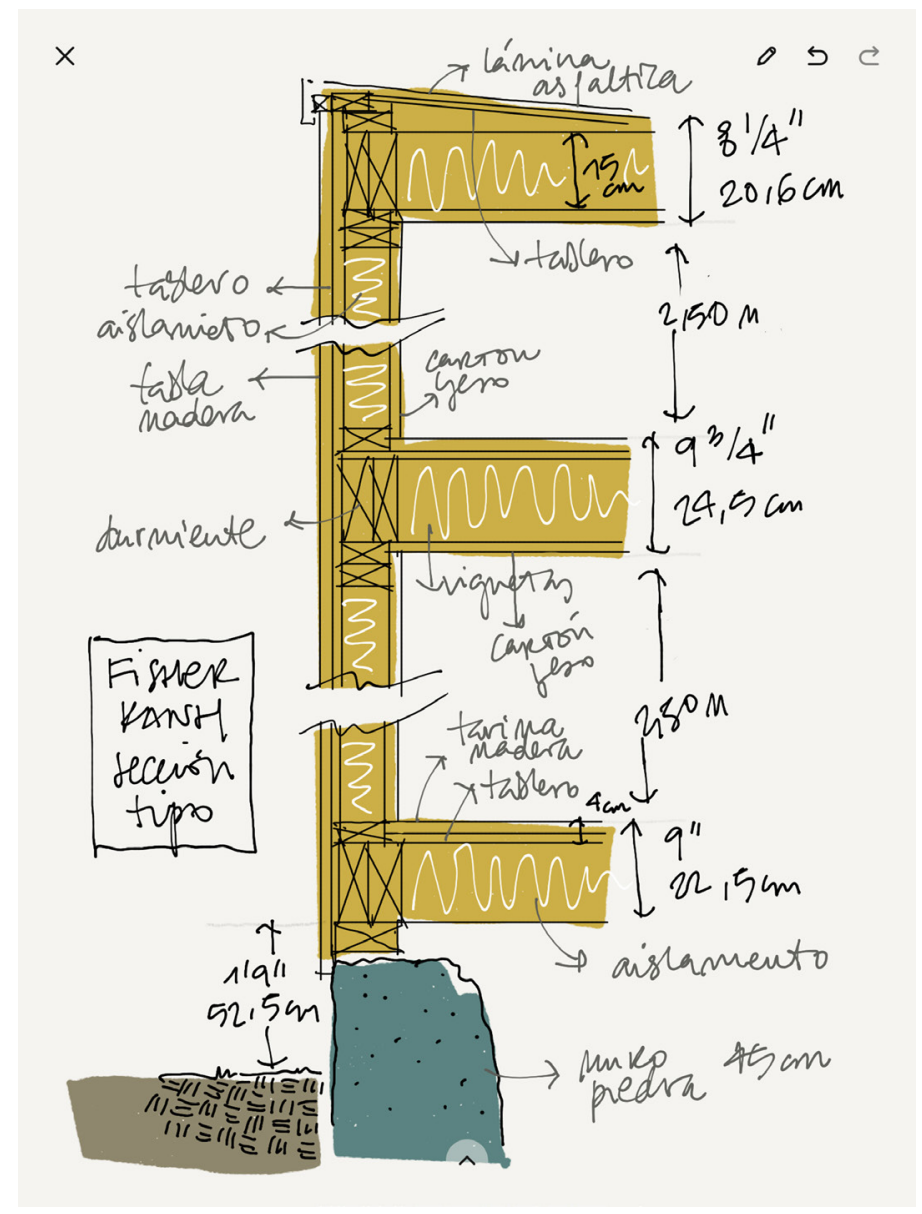

\section{Elección del modelo a copiar}

La elección del propio modelo que servirá como referencia a los alumnos es una parte primordial del sistema de docencia, pues debe de cumplir una serie de requisitos que permitan al alumno desarrollar y profundizar en los temas que se esté trabajando en ese momento. Así en asignaturas como Análisis de formas o Representación avanzada, trabajamos sobre todo con viviendas unifamiliares que tengan unos condicionantes previos, y que por su tamaño permiten al alumno examinar y analizar con detalle los pormenores de la vivienda. Además, la vivienda es un elemento que no resulta ajeno al alumno, como pudiera ser un 
museo o un aeropuerto, sino que el conocimiento previo sobre las necesidades básicas que ha podido experimentar con su propia vivencia ayuda a acercar el tema de estudio.

El disponer de un modelo a imitar permite al alumno apropiarse del original, desarrollando y asimilando conceptos inherentes a la obra. Se fomenta el conocimiento visual dejando una impronta en el alumno que le permite disfrutar de un progresivo perfeccionamiento de su sensibilidad estética.

Además, algunos de los proyectos realizados por los alumnos se tratan de arquitectura no construida, que ya no existe o de la cual falta algo de información, permitiendo este tipo de trabajos desarrollar la imaginación del alumno para completar la documentación que se les facilita. Esto hace añadir el acto de reinterpretación como medio de aprendizaje (fig. 9). El no disponer de toda la información de un proyecto, permite un acercamiento del alumno a la fase de generación del proyecto, aportando además la variable de implicación personal en la que el alumno añade su propia visión para rehacer las partes no conocidas o incompletas del proyecto.

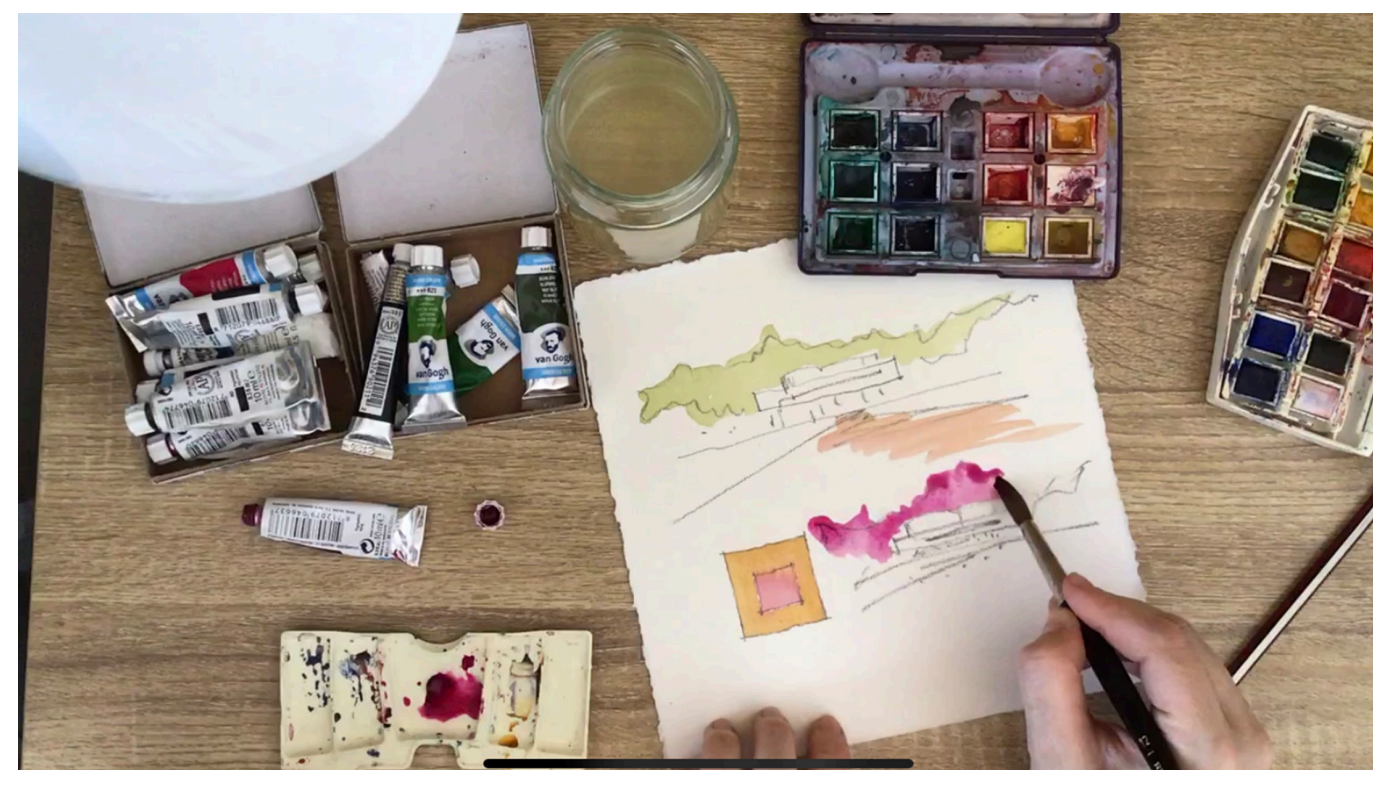

\section{Conclusiones}

Como conclusiones frente a este curso singular en el cual hemos tenido que añadir la problemática del distanciamiento social a la docencia, hemos podido comprobar la gran capacidad de adaptación que los alumnos han tenido a esta nueva casuística. La diferencia frente a la docencia presencial tradicional, aunque ha conllevado un incremento en la dedicación tanto por parte del profesor como del alumno, no se ha visto mermada en cuanto a la obtención de resultados, sino que el alumno ha encontrado recursos propios a través de sus experiencias o conocimientos que ha ido incorporando a su trabajo.

El enfoque docente empleado para el desarrollo de la segunda mitad del curso, centrado en el análisis y representación a partir de la copia de un modelo existente ha permitido a los alumnos contar con un sistema de revisión sistemático que nos permite un análisis crítico tanto del modo de representación como del diseño arquitectónico.

Los diversos medios empleados para la docencia han permitido que cada alumno descubra mediante la experimentación el medio que le resulta más apropiado para desarrollar el proyecto. Con ello hemos conseguido no sólo aprender un medio de representación, sino que encuentren su propio método de expresión y estilo propio adquiriendo un lenguaje personal. 
Fig. 8. Lámina realizada por alumnos de la

asignatura de Representación Avanzada de la arquitectura II.

Fig. 9. Lámina realizada por alumnos de
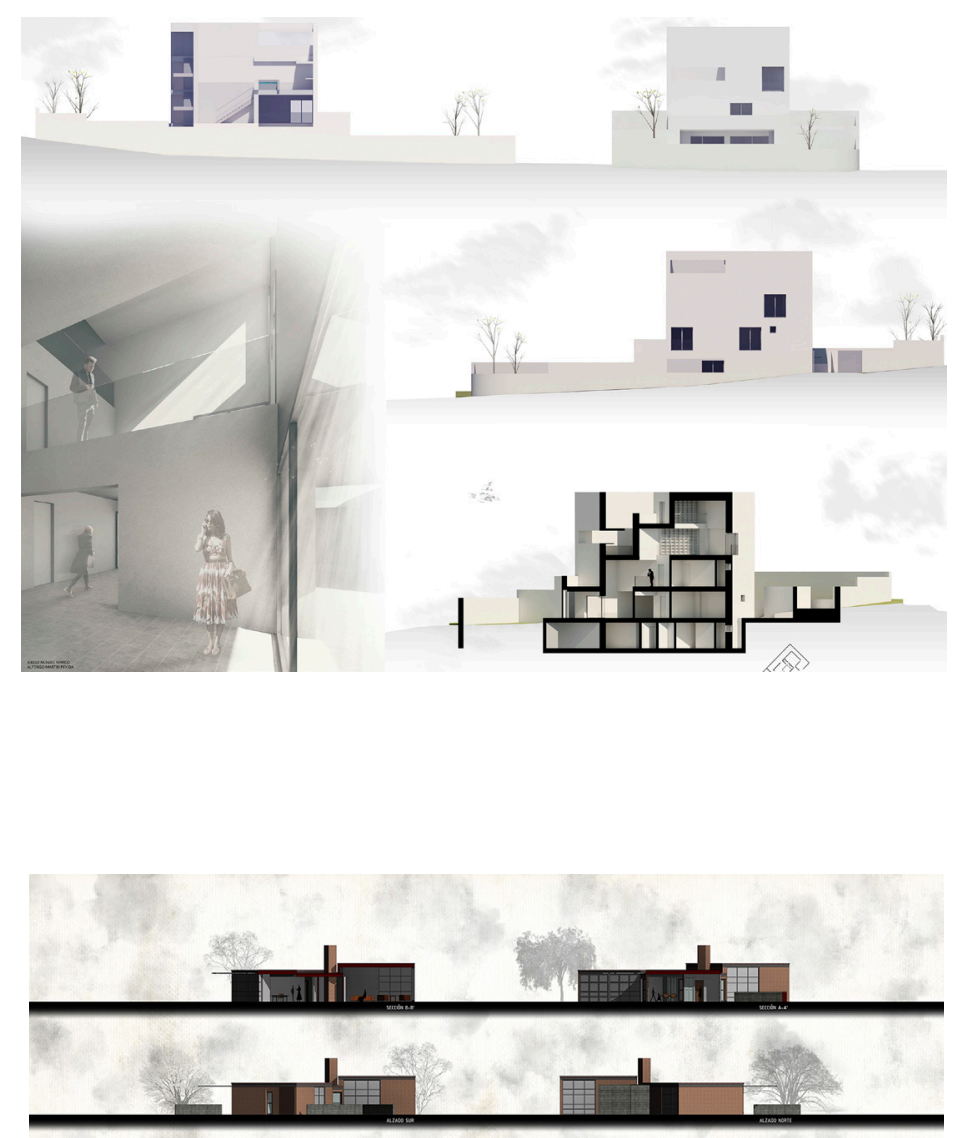

3it

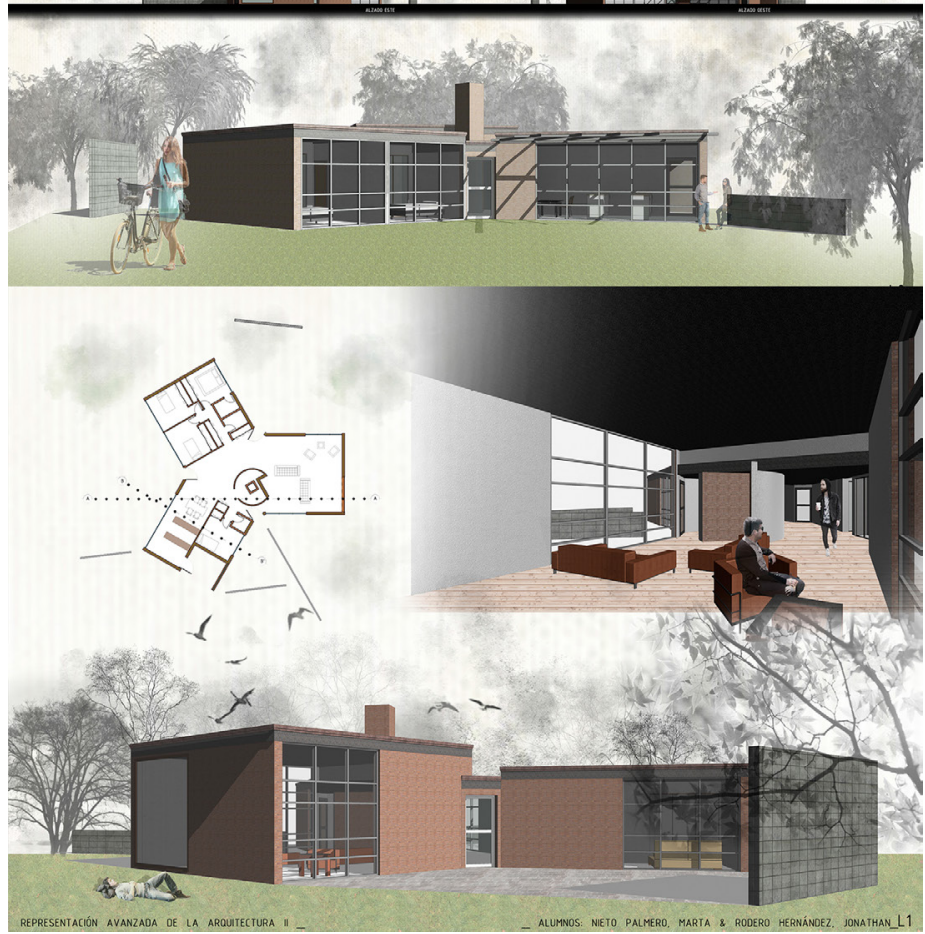




\section{Referencias}

Alonso Rodríguez M., Galván Desvaux N., Álvaro Tordesillas A. (2016). De la mente al papel. Nuevas técnicas aplicadas al dibujo de arquitectura. In E. Echeverría (Ed.). XVI Congreso Internacional de Expresión Gráfica Arquitectónica. Docencia e investigación en expresión gráfica arquitectónica. Alcalá de Henares, España, 2-4 junio 2016, vol. I, pp. 453-459. Comunidad de Madrid (España): Fundación General de la Universidad de Alcalá.

Barroso Gutiérrez M. C. (2017). Los copistas del Museo del Prado. La revalorización de la copia de maestros en el aprendizaje del artista. La importancia de la copia. PhD tesis in Educación artística. Tutor Prof. R. Naranjo López, co-tutor M. Replinger González. UAM. Departamento de Educación Artística, Plástica y Visual.

Bullón de Diego J. M. (20 I8). Disegno e idea. Teoría y práctica del dibujo a partir del renacimiento. In El Ornitorrinco Tachado. Revista de Artes Visuales, vol., n. 7, pp. 35-45: <https://ornitorrincotachado.uaemex.mx/article/view/9699> (accesed 17 de febrero de 202I).

Cantera Montenegro J. (2020). Pedro Pablo Rubens: en busca de Tiziano. In Descubrir el arte, n. 259, pp. 25-32.

Galván Desvaux N., Carazo Lefort E. (2008). Variaciones sobre un tema: Propósitos del dibujo en la obra de Louis Kahn. In E. Rabasa (Ed.). XII Congreso Internacional de Expresión Gráfica Arquitectónica. Zaragoza, 2 I-25 de septiembre de 2020, pp. 339347. Universidad Politécnica de Madrid, Escuela Técnica Superior de Arquitectura de Madrid.

Herrero-Cortell M. A. (20।8). Consideration of pictorial copies in the light of the treatises and other texts of the Renaissance: theoretical reputation ver-sus practical repercussion. In Revista de Humanidades, n. 35, pp. 8I- 106.

Marcos C. L., Domingo Gresa J. (20I5). Ideación gráfica revertida. In EGA Expresión Gráfica Arquitectónica, n. 26, pp. 68-83.

Vallespín Muniesa A., Cervero Sánchez N., Cabodevilla-Artieda I. (2017). Los collages de la casa Resor de Mies van der Roh como transparencia fenomenal. In EGA Expresión Gráfica Arquitectónica, vol. 22, n. 31 , pp. | 40- 149.

\section{Autores}

Marta Alonso Rodríguez, ETS Arquitectura Valladolid, marta.alonso.rodriguez@uva.es

Noelia Galván Desvaux, ETS Arquitectura Valladolid, noelia.galvan@arq.uva.es

Raquel Álvarez Arce, ETS Arquitectura Valladolid, raquel.alvarez.arce@uva.es

Para citar este capitulo: Alonso Rodríguez Marta, Galván Desvaux Noelia, Álvarez Arce Raquel (2021). Aprendiendo a mirar. La copia como metodología de enseñanza en las asignaturas de dibujo durante el confinamiento/Learning how to watch. Copying as learning methodolog/ in drawing courses during confinement. In Arena A., Arena M., Mediati D., Raffa P. (a cura di). Connettere. Un disegno per annodare e tessere. Linguaggi Distanze Tecnologie. Atti del $42^{\circ}$ Convegno Internazionale dei Docenti delle Discipline della Rappresentazione/Connecting. Drawing for weaving relationship. Languages Distances Technologies. Proceedings of the $42^{\text {th }}$ International Conference of Representation Disciplines Teachers. Milano: FrancoAngeli, pp. $1318-1333$. 


\title{
Learning How to Watch. Copying as Learning Methodology in Drawing Courses During Confinement
}

\author{
Marta Alonso Rodríguez \\ Noelia Galván Desvaux \\ Raquel Álvarez Arce
}

Abstract

Copying has always aroused suspicion and carries certain negative connotations. The artists of the $15^{\text {th }}$ century, for example, concealed the use of camera obscura for their drawings, since it was thought that this 'copy' of reality using a device external to the artist's own skill detracted from their representations. We find a certain similarity between this idea that accepts with some suspicion the use of other means for representation, and the use of new technologies to draw.

This new stage of teaching, that has made us face new problems such as distance and the lack of supplies in many cases, the return to copying as a teaching resource has made it easier for us to provide students of an existing example to represent. This fact, however, has not eliminated the imaginative part or the creative freedom, but has allowed to establish a solid base from which each student has been able to develop their inventiveness and explore various means of representation. The 'writer's block' disappears, since it starts from an already consolidated example and the creative process is streamlined, allowing the student to break the barrier of teacher-student distance in that initial stage of the representation.

Keywords

drawing, education, copy, confinement, distance.

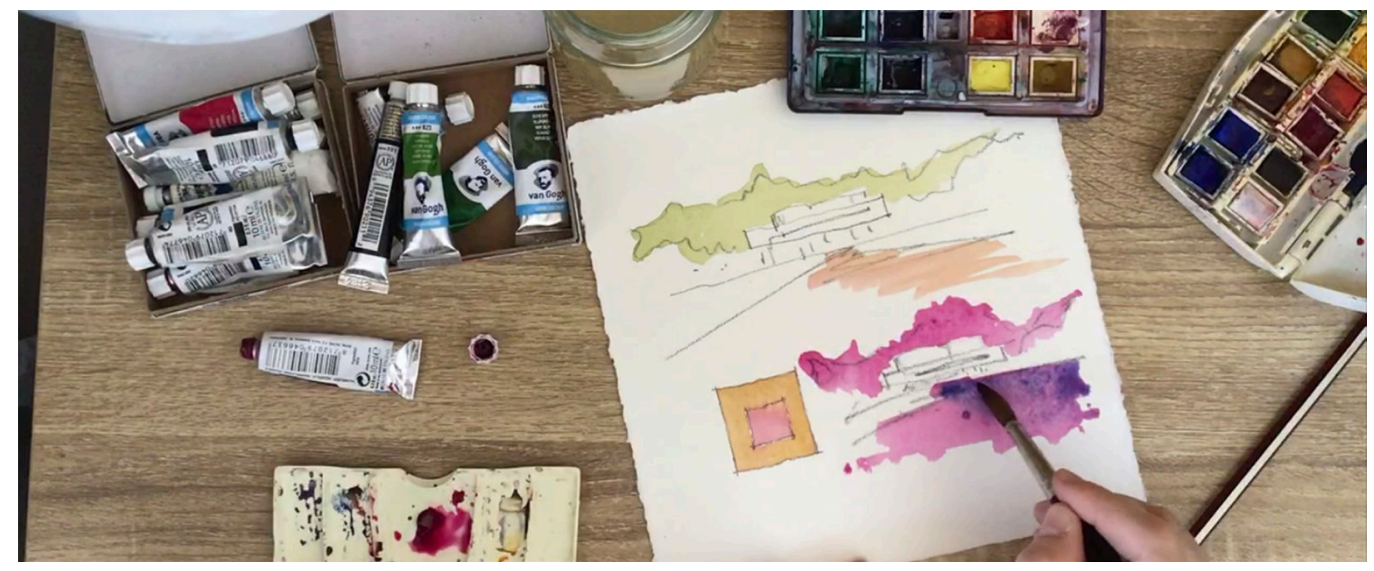




\section{Introduction}

Although we don't know the copy's exact origin, we can point out that, in the art world, the Renaissance was its flowering moment, as learning process and as means of reproduction of an original model, in order to be disseminated [Herrero-Cortell 2017]. Copying the art masters, as a learning method, has been one of the first teaching systems employed.

It is a practice whose effectiveness is more than proven, since through imitation and copying it is possible to assimilate concepts and knowledge. As copying the great classics in order to learn how to paint has been used in the world of painting, we consider that this system is perfectly extrapolated to the world of architectural representation. In our field copying is not only learning from the project method, delving into how the architect relates spaces or construction systems, but the style of representation used by the architect himself serves as inspiration for the student.

The copy has had various nuances depending of its use. From the representations made in the tombs of ancient Egypt, which copied and reproduced the same gods over and over again for mystical purposes, to the religious reproductions made in the Middle Ages for doctrinal or evangelical purposes, passing through the most trivial that could be considered, the propaganda purpose, the copy has acquired different connotations over the centuries [Barroso 2017, pp. 22, 23].

As we pointed out before, the Renaissance was a turning point for copying, with the appearance of speculation about the artistic work that led to the creation of artists' workshops where apprentices worked with a master following a style that in many cases made it impossible to distinguish the actual author of a work (fig. I). This made possible to the art masters to increase their artistic production, which in some cases even saw its price modified depending on how much there was of their own hand in the painting. In the 19th century, copying as a learning discipline again took on great importance, in fact, as Barroso [2017, p. 26] states, this practice carried out by numerous artists meant turning

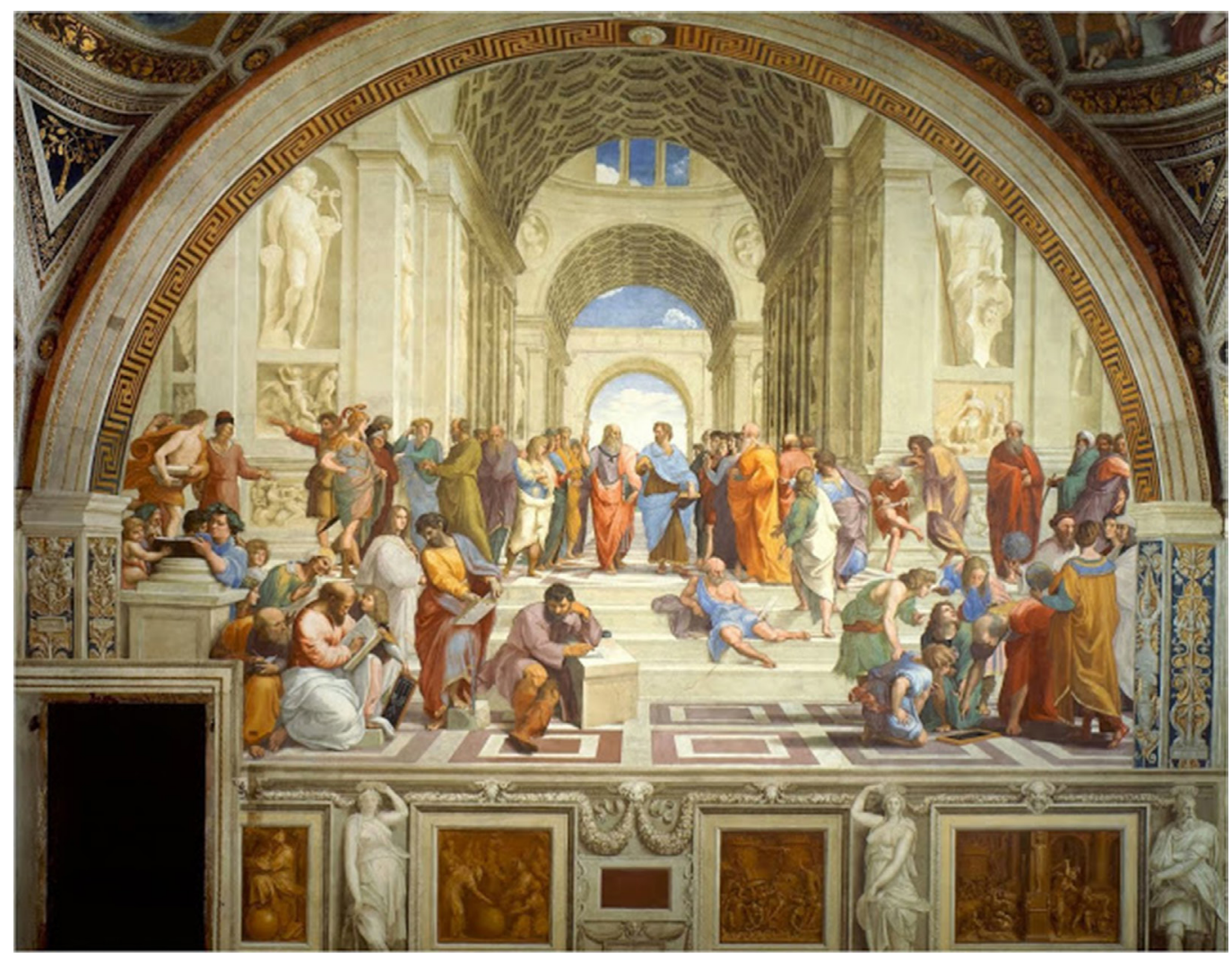


the great European museums into meeting places where painters came, for example Édouard Manet coinciding with Edgar Degas in front of the portrait of the Infanta Margarita, a painting that both were copying and thus establishing a friendship that lasted for years. Not only apprentices used copying as a learning method, but established artists also used this technique. For example, Rubens, a great admirer of Titian's work, made two trips to Spain in which he dedicated himself to copying the pictures ofT itian that the King of Spain had in his collection. Some of them were literal copies and in others he introduced small modifications, his work being a tribute to the original, and assuming the work of Titian a source of inspiration to carry out an investigation into his pictorial style creating his own versions of the initial works [Cantera 2020].

Being instructed through the copy of an artistic work not only makes it possible to train the hand, but also allows to deepen and learn from another artist's style, which favors the creation of one's own style by molding what has been learned, acquiring a personal language.

It was a common practice, for example in illustration, to complete the education of architects and artists in general with a trip to Europe to soak up the classics, especially traveling to Italy. This learning system is none other than the copy, naturally, of course, of an existing element in order to apprehend the element to represent. This idea of the Grand Tour actually dates back to the Renaissance, when artists who could afford it traveled to acquire new knowledge and expand their minds (fig. 2). Among the architects who decided to learn through copy from the great classical works we find Le Corbusier, Gropius or Asplund. In this era in which we find ourselves, in which traveling has become impossible, the explosion of drawings and information that we can find on the internet have allowed us to bring these elements closer together and to be able to represent them from images. The idea of going back to the beginning of architecture learning, in which copying was used as a starting point, leads us to a graphic and learning reflexion. This was also driven by the ease of transferring information and share resources allowed by digital platforms and the computer tools, breaking the isolation suffered by the student through the confinement.

Fig. 2. Álvaro Siza, Travel sketch.

Fig. 3. Model of the Stone house in Cáceres ( $E$. Tuñón, student of the course Form Analysis II).
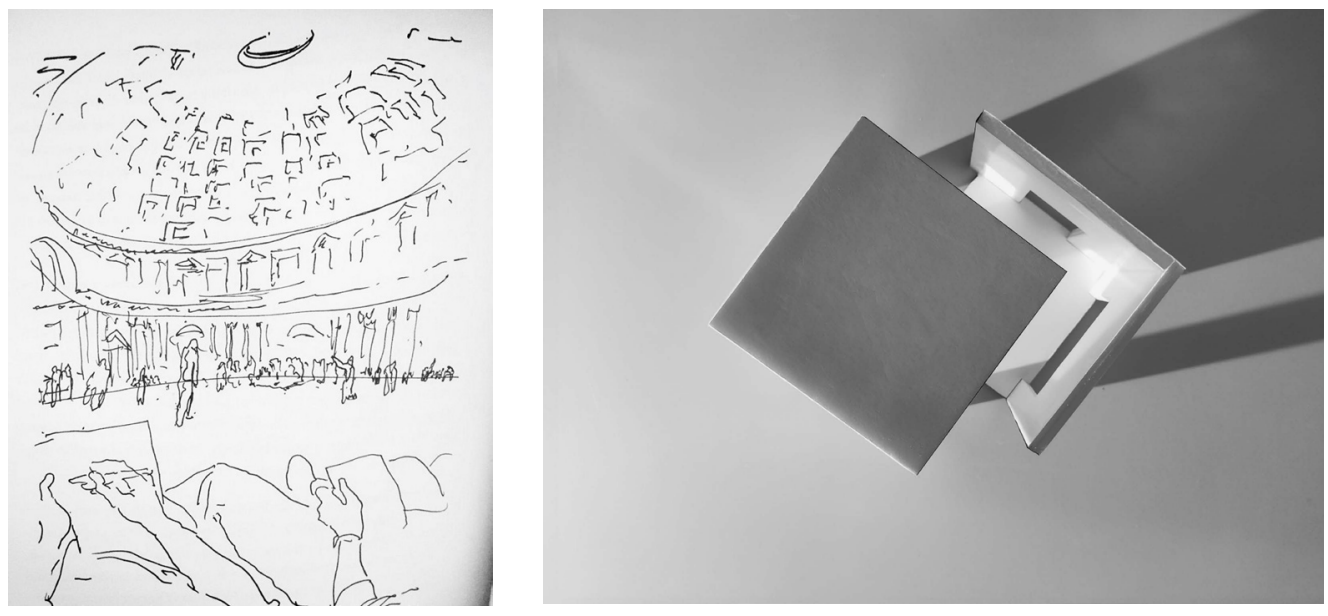

\section{Lack of resources as a driving force}

We have found a duality, in which we had web platforms and state-of-the-art programs for the development of the courses, and at the same time the evident lack of resources on the part of the students who in many cases could not even have paper to draw. This fact, however, led to an explosion of wit on the part of the students, who discovered the potential that any everyday object had as an element of representation. 
Thus, in a mere cardboard packaging they found the perfect medium for the construction of a model, and from a composition of old papers they structured a sheet. Undoubtedly, the parallelism between this technique that arose out of necessity and the collage technique can be appreciated. As numerous followers through history, among which we highlight the Bauhaus, collage creations were one of the techniques most used by students (fig. 4).

The reuse of materials gave the students the opportunity to reinvent themselves, and together with new technologies, they result in compositions where expressiveness becomes the true protagonist (fig. 5).

Fig. 4. Form Analysis II exercise made with the collage technique.

Fig. 5. Model of the Finney house by $P$. Rudolph, made by a student of Form Analysis with recycled materials.
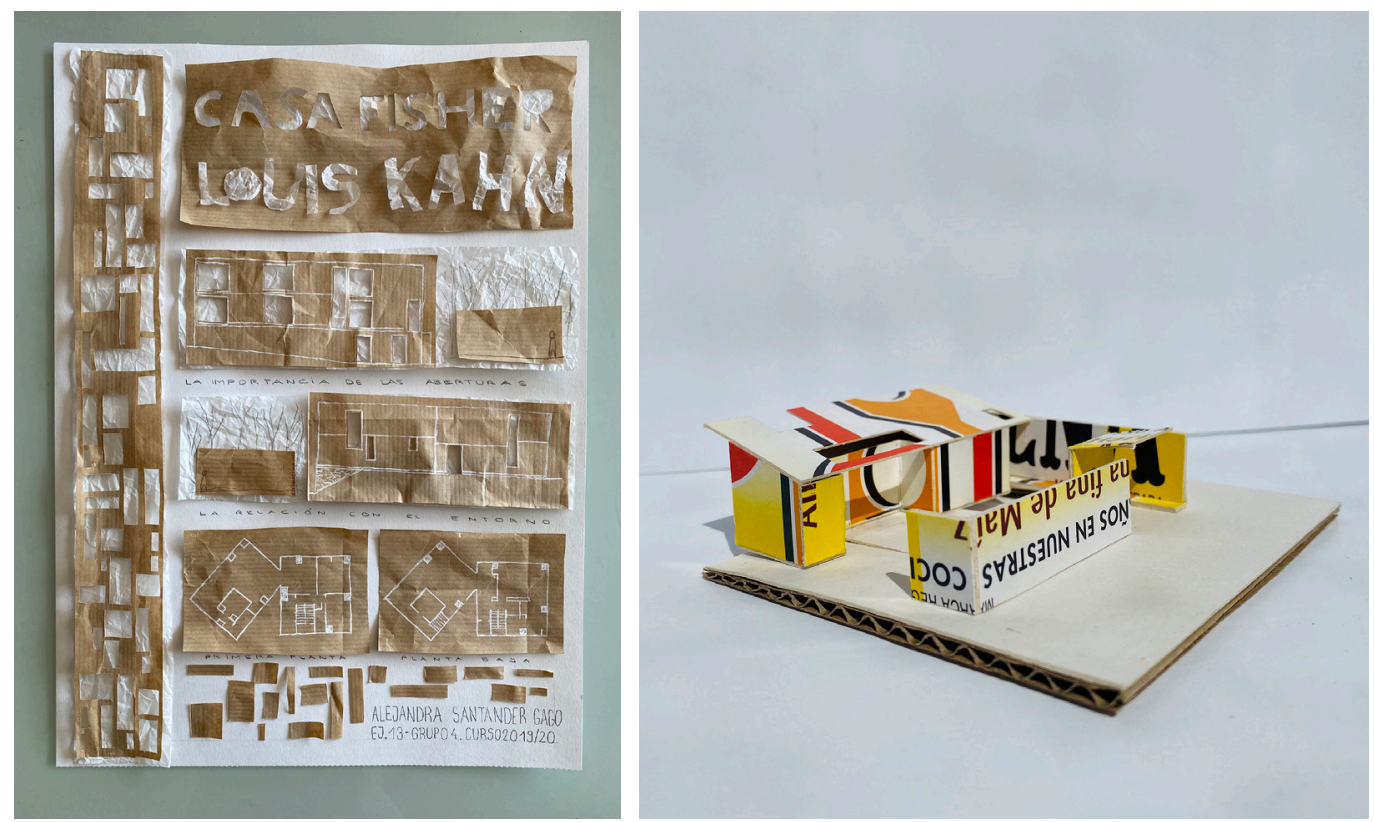

\section{New technologies applied to online learning}

Many artists such as Vermeer or Canaletto kept their techniques secret, perhaps thinking that the use of external means made it seem that anyone could knew how to draw. Thus, cameras obscura and the knowledge of optics and other gadgets remained hidden for centuries. These inventions undoubtedly did not give the artist skills, but rather facilitated the work of drawing. In our opinion, to the new 'dark cameras' that we have today are tablets and computers. The use of these elements as then, brings us an advantage that is more than evident, and in which at least we will all agree, which is the speed of the drawing process (fig. 6).

Hand drawing is complemented by the mastery of virtual media, which gives students freedom to allow them to explore new techniques and materials (fig. 7). Thus, the online classes of the Form Analysis I/ course have been developed by combining hand drawings and physical models that could be seen through the webcam, and drawings on a digital tablet or computer. Each of the graphic methods used has helped the student to find the means of expression with which to best develop their ideas, making it easier for each one to discover which is most appropriate for each purpose, either to capture an idea or explain a concept Although computer drawing may seem a priori more restrictive than hand drawing, using the appropriate software allows us to squeeze all the potential it offers us, and the results obtained show us that the expressiveness of hand drawing is not diminished by use of the 
computer. Graphic tablets allow a very natural transition from freehand drawing with a pencil, and also give us the advantage of facilitating changes on the drawing very quickly, allowing faster corrections and the use of layer overlays in the same drawing.

However, after our teaching experience, we consider that, regardless of the technique used, the fact of using drawing as a thinking instrument goes beyond the medium used for this purpose.

Counting on examples previously chosen by the professor, the student gradually relies on virtual media as a complement to traditional teaching techniques (fig. 8). These virtual classes supported by new technologies allow the creation of professor-student feedback that proposes learning strategies that allow them to develop the ability to think and intervene in the various processes of creation and ideation of a project

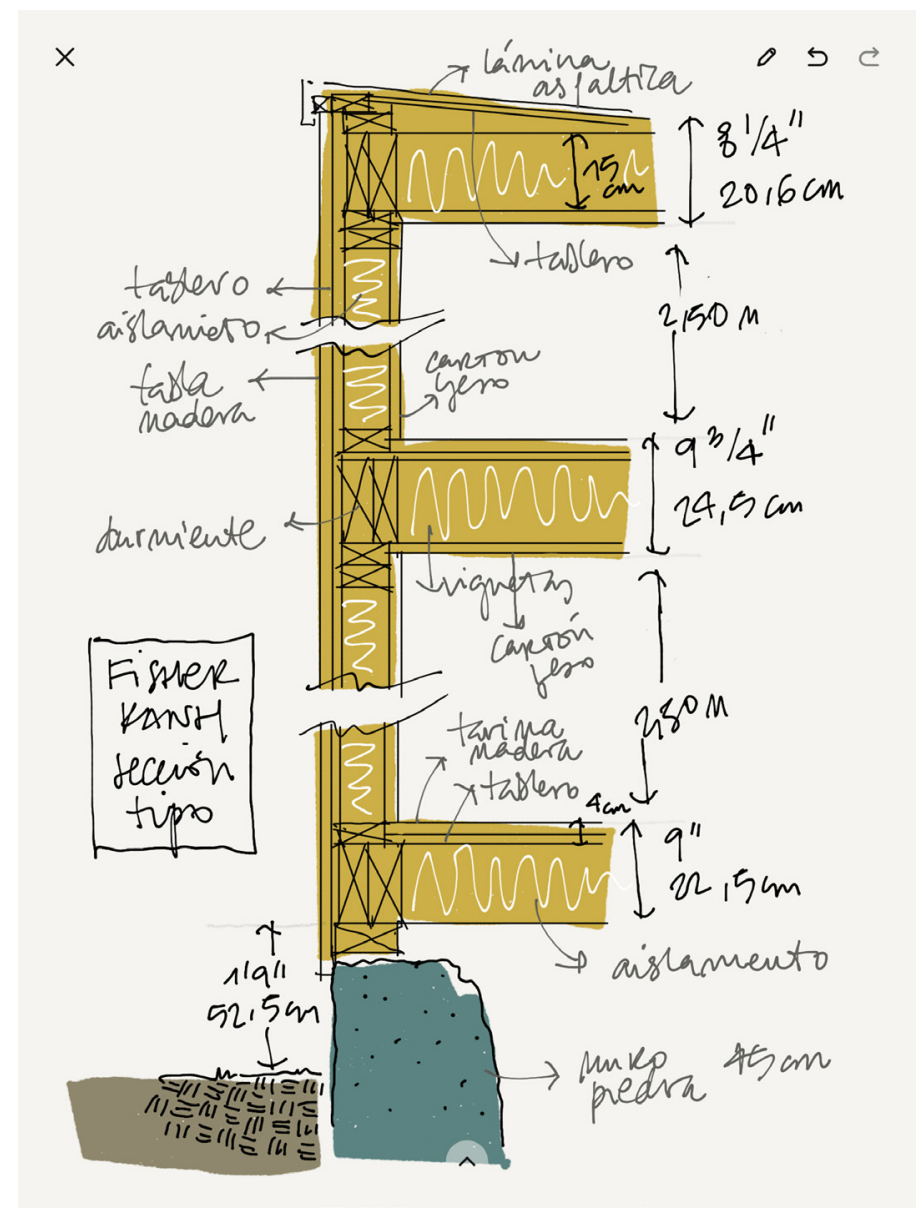

\section{Picking out the model to copy}

The choice of the model that will serve as a reference to the students is an essential part of the teaching system, as it must meet a series of requirements that will allow the student to develop and deepen the topics that are being worked on at that time. Thus, in courses such as Analysis of Forms or Advanced Representation of Architetcure II, we work mainly with single-family homes that have previous conditions, and that due to their size allow the student to examine and analyze in detail the characteristics of the home. In addition, housing is an element that is not unknown to the student, such as a museum or an airport, so the 
prior knowledge about the basic needs that they have been able to experience helps to bring the subject of study closer.

Having a model to imitate allows the student to appropriate the original, developing and assimilating concepts inherent to the work. Visual knowledge is promoted, leaving an imprint on the student that allows him to enjoy a progressive improvement of his aesthetic sensitivity.

In addition, some of the projects carried out by the students are about non-built architecture, which no longer exists or for which some information is missing, allowing this type of work to develop the student's imagination to complete the documentation provided to them. This adds the act of reinterpretation as a means of learning (fig. 9).

Not having all the information of a project, allows the student to approach the project generation phase, also providing the variable of personal involvement in which the student adds their own vision to redo the unknown or incomplete parts of the project.

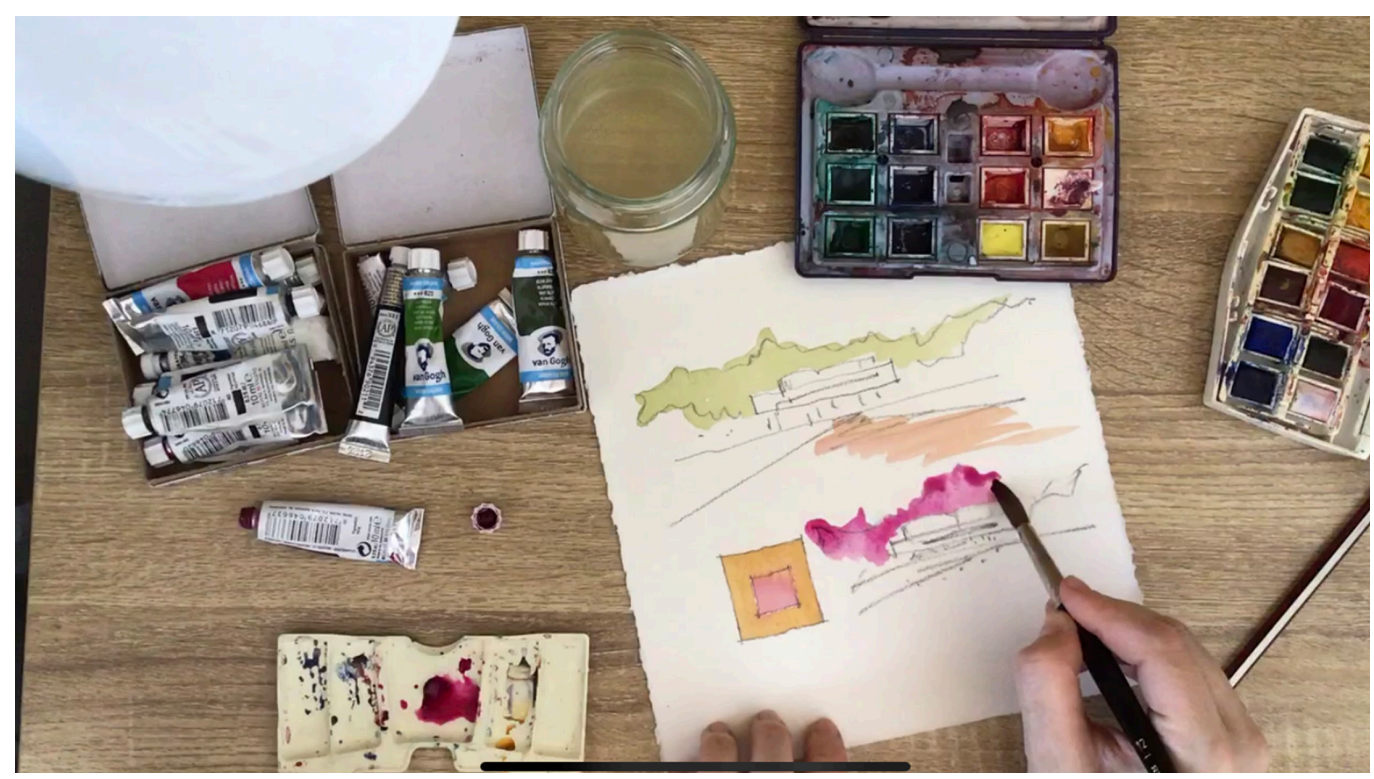

\section{Conclusions}

As conclusion regarding this singular course in which we have had to add the problem of social distancing to teaching, we have been able to verify the great capacity for adaptation that students have had in this new casuistry. The difference compared to traditional face-toface teaching, although it has led to an increase in dedication by both the professor and the student, has not been diminished in terms of obtaining results, but the student has found their own resources through their experiences or knowledge that they have been incorporating into their work.

The teaching approach used for the development of the second half of the course, focused on the analysis and representation of the copy of an existing model, has allowed students to have a systematic review system that allows us a critical analysis both of the representation as well as architectural design.

The various means used for teaching have allowed each student to discover through experimentation the means that are most appropriate for developing a project. With this we have managed not only to have them learn different means of representation, but also to find their own method of expression and their own style by acquiring a personal language. 
Fig. 8. Print made by

students of the Advance representation of a
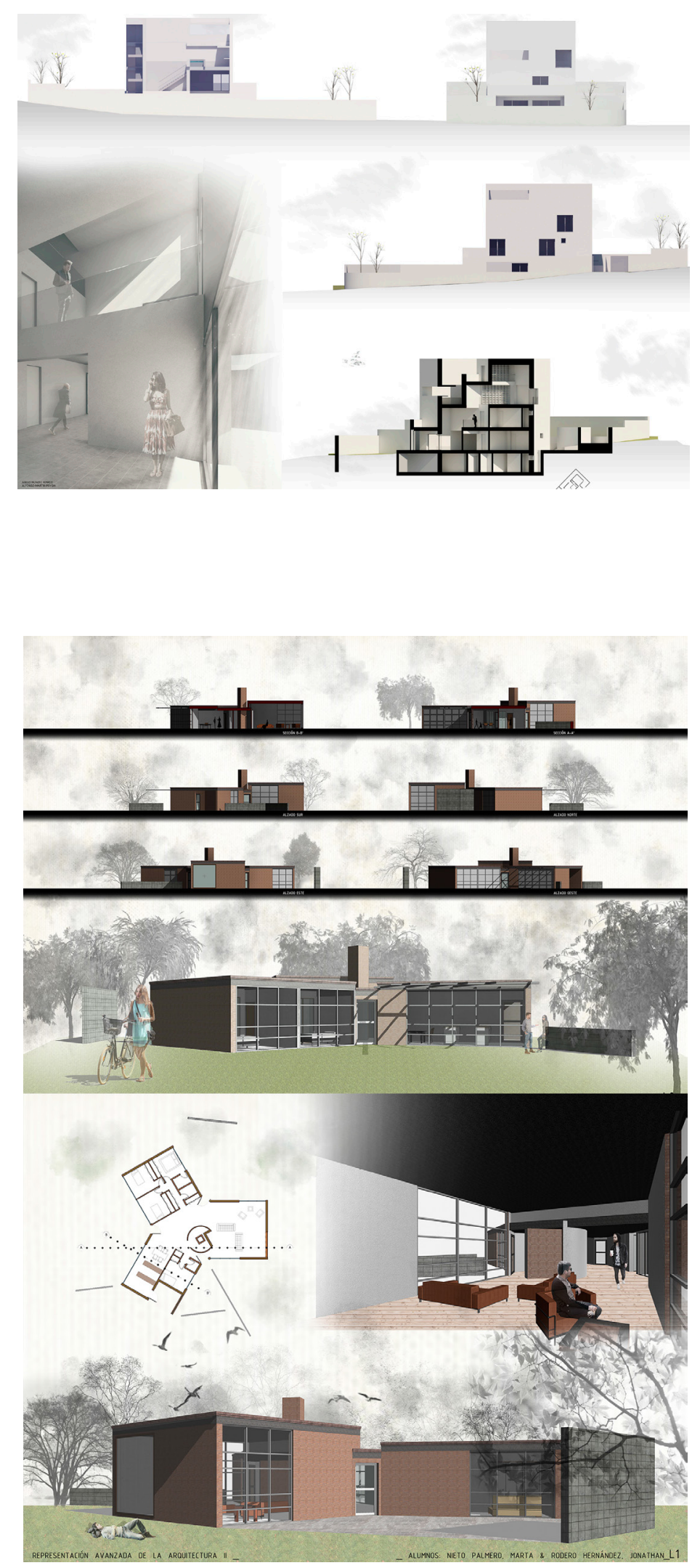


\section{References}

Alonso Rodríguez M., Galván Desvaux N., Álvaro Tordesillas A. (2016). De la mente al papel. Nuevas técnicas aplicadas al dibujo de arquitectura. In E. Echeverría (Ed.). XVI Congreso Internacional de Expresión Gráfica Arquitectónica. Docencia e investigación en expresión gráfica arquitectónica. Alcalá de Henares, España, 2-4 junio 20I6, vol. I, pp. 453-459. Comunidad de Madrid (España): Fundación General de la Universidad de Alcalá.

Barroso Gutiérrez M. C. (2017). Los copistas del Museo del Prado. La revalorización de la copia de maestros en el aprendizaje del artista. La importancia de la copia. PhD tesis in Educación artística. Tutor Prof. R. Naranjo López, co-tutor M. Replinger González. UAM. Departamento de Educación Artística, Plástica y Visual.

Bullón de Diego J. M. (20 I8). Disegno e idea. Teoría y práctica del dibujo a partir del renacimiento. In El Ornitorrinco Tachado. Revista de Artes Visuales, vol., n. 7, pp. 35-45: <https://ornitorrincotachado.uaemex.mx/article/view/9699> (accesed 17 de febrero de 2021).

Cantera Montenegro J. (2020). Pedro Pablo Rubens: en busca de Tiziano. In Descubrir el arte, n. 259, pp. 25-32.

Galván Desvaux N., Carazo Lefort E. (2008).Variaciones sobre un tema: Propósitos del dibujo en la obra de Louis Kahn. In E. Rabasa (Ed.). XII Congreso Internacional de Expresión Gráfica Arquitectónica. Zaragoza, 2 I-25 de septiembre de 2020, pp. 339347. Universidad Politécnica de Madrid, Escuela Técnica Superior de Arquitectura de Madrid.

Herrero-Cortell M.A. (20।8). Consideration of pictorial copies in the light of the treatises and other texts of the Renaissance: theoretical reputation ver-sus practical repercussion. In Revista de Humanidades, n. 35, pp. 8I- 106.

Marcos C. L., Domingo Gresa J. (20 I5). Ideación gráfica revertida. In EGA Expresión Gráfica Arquitectónica, n. 26, pp. 68-83.

Vallespín Muniesa A., Cervero Sánchez N., Cabodevilla-Artieda I. (2017). Los collages de la casa Resor de Mies van der Roh como transparencia fenomenal. In EGA Expresión Gráfica Arquitectónica, vol. 22, n. 31, pp. I 40- 449.

\section{Authors}

Marta Alonso Rodríguez, ETS Arquitectura Valladolid, marta.alonso.rodriguez@uva.es

Noelia Galván Desvaux, ETS Arquitectura Valladolid, noelia.galvan@arq.uva.es

Raquel Álvarez Arce, ETS Arquitectura Valladolid, raquel.alvarez.arce@uva.es

To cite this chapter: Alonso Rodríguez Marta, Galván Desvaux Noelia, Álvarez Arce Raquel (202I). Aprendiendo a mirar. La copia como metodología de enseñanza en las asignaturas de dibujo durante el confinamiento/Learning how to watch. Copying as learning methodology in drawing courses during confinement. In Arena A., Arena M., Mediati D., Raffa P. (a cura di). Connettere. Un disegno per annodare e tessere. Linguaggi Distanze Tecnologie. Atti del $42^{\circ}$ Convegno Internazionale dei Docenti delle Discipline della Rappresentazione/Connecting. Drawing for weaving relationship. Languages Distances Technologies. Proceedings of the $42^{\text {th }}$ International Conference of Representation Disciplines Teachers. Milano: FrancoAngeli, pp. $1318-1333$ 